\title{
Lords look for culprits
}

\section{London}

THE UK House of Lords Science and Technology (S\&T) Committee, which is investigating the financial crisis that followed the announcement of the 1991-92 science budget, will find no shortage of people to blame, if its first hearing is anything to go by.

The S\&T committee aims to discover why the Science and Engineering Research Council (SERC) was forced to make swingeing cuts across its research programme after his year's budget was announced (see Nature 349, 551; 14 February 1991). But Sir Peter Swinnerton-Dyer, chief executive of the Universities Funding Council (UFC), last week told the S\&T committee that SERC's current problems cannot be considered simply in the context of this year's budget, and accused SERC's previous chairman, Sir William Mitchell, of overstretching the council's resources by committing SERC to a series of expensive, long-term projects.

SERC's "day of reckoning" is the end result of a long-running crisis in British science, which is one of overdemand as well as underfunding, Swinnerton-Dyer suggested. In Britain, there is more research "waiting to be done" than any government could be expected to fund, he said, but towards the end of Mitchell's five-year reign, SERC failed to recognize this. British science administrators need to manage the country's research priorities more efficiently, according to Swinnerton-Dyer. Relying on increased funds from next year's science budget to cover future spending is "no longer an acceptable frame of thought".

SERC's current efforts to trim its programme, and to review the balance of its spending between "big science" facilities and small project grants, suggest that SERC is now actively reconsidering its priorities in the light of limited government funding. (The decisions announced so far, however, have met with widespread protest, notably the threatened closure of the Nuclear Structure Facility at SERC's Daresbury Laboratory.)

But Swinnerton-Dyer made clear his dissatisfaction with the UFC's absence from the main forum of debate over the science budget, the Advisory Board for the Research Councils (ABRC). As chairman of the UFC's predecessor, the University Grants Committee, Swinnerton-Dyer sat on the ABRC, but UFC chairman Lord Chilver insisted in 1989 that the new body should divorce itself from British research planning.

The ABRC's advice on research council funding affects the universities, but "the UFC has virtually not been consulted at all", over SERC's current difficulties, Swinnerton-Dyer told the S\&T committee. Because few savings on large projects are possible this year, the vast majority of SERC's cuts in 1991-92 have fallen on project grants and research studentships, most of which are awarded to university researchers.

SERC's chairman, Sir Mark Richmond, last week defended SERC against the accusations of lax financial management in the past, first levelled by Education and Science Secretary Kenneth Clarke. He told the S\&T committee that the council's assumption that it would be given $£ 40$ million of new money for 1991-92 was "not wildly unreasonable" - an identical sum had been allocated for 1989-90. But he conceded that the $£ 40$ million figure may have been larger than warranted by the worsening state of the British economy, and the consequent tightening of the government's purse strings. In the event, SERC receive only $£ 12$ million above its "baseline" funding.

Swinnerton-Dyer also told the S\&T committee that he is worried about the planned transfer of funds from the UFC to the research councils to cover the indirect costs of research council funded projects in the universities. This transfer begins with some $£ 50$ million in 1992-93. Swinnerton-Dyer said that SERC will be "under extraordinary pressure" to use the money to ease its own financial difficulties, rather than returning it to the universities to cover research overheads.

Peter Aldhous

\section{MEDICAL RESEARCH World's first MS unit} London

The Multiple Sclerosis Society, a British charity, announced last week that it will spend nearly $£ 2$ million to set up the world's first research unit that will combine basic and clinical science to investigate multiple sclerosis (MS), the most common disease of the central nervous system.

Alan Davison, chairman of the society's research advisory committee, says the move was prompted by the decline in UK government support for medical research. These cuts, he says, mean that researchers in universities "now have to divert more of their time to teaching and clinical work".

In response, the medical research charities have taken over an increasing proportion of British medical research funding over the past decade, and now spend more each year in the universities than the Medical Research Council (MRC). And charitable societies are increasingly considering funding their own institutes, says Diana Garnham from the Association of Medical Research Charities (AMRC). This has been particularly evident in cancer research.

The new MS unit, which Davison hopes will open before the end of the year, aims to draw together the many strands of research into the disease, including immunology, virology and epidemiology, as well as neuroscience. The site has yet to be chosen. Peter Aldhous

\section{Moneysaving measures}

\section{London}

LAST week, SERC chairman Sir Mark Richmond offered an appealing method for avoiding some of the cash crises that often plague the British funding of science. Speaking before the House of Lords Science and Technology (S\&T) Committee, Richmond suggested that SERC be allowed to carry over as much as five per cent of its budget from one year to the next. In this way, the council could save money in years of plenty to use in leaner times.

SERC's problems, Richmond said, stem from the variability in government funding for science from year to year. In 1991-92, as much as $£ 28$ million of SERC's predicted shortfall is due to the failure of the science budget to keep pace with inflation and salary increases. As most of SERC's financial commitments run over a number of years, it would be "very helpful" if SERC could smooth out the variability in government funding, Richmond said. SERC is already allowed to carry over some of its budget from one year to the next, but only two per cent. Richmond wants that increased to five per cent of the annual budget, which would give SERC about $£ 20$ million to tinker with.

One potential problem with such a plan is that the Treasury may be tempted to reduce the science budget further if the largest research council is not spending all its funds in years of relative prosperity. Similar fears plague Japanese research spending, resulting in a profligate "end of year splurge" to spend research grants before the end of each fiscal year. Richmond's aides agree that is a risk, and say the issue must be addressed before SERC agrees to reforms, the Department of Education and Science has to argue the case with the Treasury, and SERC officials say no reforms are likely for a year or two.

Richmond also argued last week that subscriptions to international scientific programmes, which account for almost one third of SERC's spending, should be "ringfenced", so that increases beyond SERC's control do not reduce spending on domestic science. Richmond would like to see some money provided from outside SERC's budget to pay for cost overruns caused by fluctuating currency exchange rates or inflation in other countries.

Like Sir Peter Swinnerton-Dyer (see left), Richmond believes the outlook of the Advisory Board for the Research Councils (ABRC), which advises the Education and Science Secretary on the science budget, is too narrow. "I'm not convinced", he said, that the ABRC takes enough account of the views of the Foreign Office which is responsible for many of the intergovernmental agreements governing SERC's contribution to international science projects.

Peter Aldhous 